\title{
The Misinterpretation of Pigouvian Taxes
}

\author{
Annegrete Bruvoll \\ Research Department, Statistics Norway, Oslo, Norway. \\ Email: annegrete.bruvoll@vista-analyse.no \\ Received April 26 ${ }^{\text {th }}, 2013$; revised June $1^{\text {st }}, 2013$; accepted July $15^{\text {th }}, 2013$ \\ Copyright (C) 2013 Annegrete Bruvoll. This is an open access article distributed under the Creative Commons Attribution License, \\ which permits unrestricted use, distribution, and reproduction in any medium, provided the original work is properly cited.
}

\begin{abstract}
The tax revenues from Pigouvian taxes are difficult to calculate. The optimal pollution taxes are weighted averages of Ramsey taxes and Pigouvian taxes, and the entanglement of environmental, fiscal and other taxes complicate the measurements. The present international environmental tax statistics do not rely on a theoretical basis, and include several fiscal and resource taxes. Starting with the additivity theorem by Sandmo [1], we propose theoretically consistent guidelines for environmental tax statistics. Calculations based on this framework prove that the present international official statistics (Eurostat, IEA, OECD) severely overestimate environmental taxes. The lack of theoretical consistency forms arbitrary results and the statistics used as measures of environmental taxes may cause major flaws in research and policy-making based on such statistics.
\end{abstract}

Keywords: Environmental Taxes; Fiscal Taxes; Pigouvian Taxes; Ramsey Taxes

\section{Introduction}

Taxes and tradable permits are cost efficient instruments in internalizing negative externalities. Statistics on the use of such taxes can be usable in several contexts. In international policy comparisons, environmental taxes are frequently used as indicators of environmental concerns. Environmental tax statistics are potentially valuable inputs in environmental instruments efficiency analyzes, and the environmental economics literature advocates recirculation of emission tax and permit revenues to reduce efficiency losses, c.f the double dividend literature (Bovenberg [2], Goulder and Parry [3]).

Great effort is devoted to measuring environmental taxes and tax revenues in international statistical agencies. The OECD, Eurostat and the IEA have set in place explicit routines for the definition, collection and publishing of environmental tax data across OECD countries (Eurostat $[4,5]$. OECD [6,7]), hereafter referred to as the "international statistics". In their ongoing work on a manual for environmental economic accounting, the UN seems to follow the same approach (United Nations [8]). In this article, we show that the international statistics are misleading in that they depart from the theoretical definition of environment taxes.

According to economic theory, environmental taxes should correct the marginal effects of environmental ex- ternalities, and the optimal environmental tax rate equals the marginal damage cost (Pigou [9]). The tax revenue becomes the product of the environmental tax and the tax base. When moving from theory to practice, measuring the extent of environmental tax rates and revenues is far from straightforward for two main reasons. First, the presence of both environmental and fiscal taxes influences the optimal tax structure (Sandmo [1]). Only part of the tax on the externality should count as correction for the externality. Second, the entanglement of different forms of taxes complicates the statistical definitions. Part of the taxes on polluting goods relates to externalities, while other parts may be politically motivated in fiscal concerns, income distribution or as corrections for other market failures. Although theory advocates one instrument per target, in practical policy, each political target involves use of several types of instruments, and each instrument is adjusted to achieve several targets (Bye and Bruvoll [10]). This complicates the calculations of how large parts the tax should be ascribed to the environmental elements. Taxes may be described and incorrectly labeled as environmental, even if there is no or only a small direct link with the environmental externalities.

The statistics developed by the OECD, Eurostat and the IEA cover all tax bases that have a "... particular environmental relevance", i.e., taxes related to energy, transport and pollution, as well as taxes levied on re- 
sources (Eurostat [4], OECD [6,7]) ${ }^{1}$. The statistics then clearly include additional elements, such as fiscal taxes and resource rents, and can per definition not be interpreted as environmental taxes as defined by economic theory.

Data failures may have important implications for scientific analyses, and for the comparisons of environmentally friendly policies. Sterner and Köhlin [13], for instance, use the international statistics and conclude that European countries have consistently higher levels of environmental tax revenue than the USA, and Ekins [14] states that the environmental taxes comprise an increasing proportion of total tax burden in European countries up to 1994. Eurostat [5] concludes that there has been a steady fall in environmental taxes from 2003 to 2008, after which the level has remained constant. These conclusions are not reliable, since the data include large shares of other taxes than environmental taxes. In an econometric analysis, Morley [15] rejects the double dividend theory ${ }^{2}$ applying the Eurostat data set, and concludes that environmental taxes have had a negative effect on economic growth. In fact, what this study shows is that environmental taxes and fiscal taxes reduce growth, which does not enlighten the double dividend theory. Failures in the statistical foundation may lead scientists and politicians to draw misleading conclusions on the causes and effects of environmental policy. In the end, such information failures can bring along wrong advice to the decision makers and a less efficient environmental policy.

This paper discusses the separation of environmental taxes from other taxes in light of tax theory and suggests solutions to the classification problems disturbing the official international statistics. Following Pigou [9], the proper tax base is the environmental externality, or the most closely related tax base. We take the additivity theorem by Sandmo $[1,16]$ as a starting point, and propose theoretically consistent guidelines on how to disentangle and consistently calculate the environmental tax elements. The aim is to improve the data quality and the scientific basis for analyses of environmental instruments.

We illustrate the consequences of the measurement problems empirically by calculating the revenues from the environmental taxes based on our guidelines and compare our results with the tax revenues defined and

\footnotetext{
${ }^{1}$ Indeed, the international framework uses the term environmentally related taxes in their original definition. However, the meaning is clearly to illuminate the trends in environmental policy, and the term "environmental taxes" is normally used in reports of the international statistics. E.g. Eurostat [5] uses this concept when reporting the latest version of the international data base, other examples are European Environment Agency [11] and OECD [12].

${ }^{2}$ The double dividend refers to an increase in environmental taxes reducing levels of emissions as well as increasing economic growth.
}

published as official international statistics, taking Norwegian taxes as an example. Our conclusion is that the present international statistics tend to significantly overestimate the taxes and tax revenues; in our example, by more than five times the actual environmental taxes. This gives an incorrect picture of the environmental policy in and between countries and the potential efficiency improvement by tax revenue recycling. Using the international statistics as environmental tax estimates, analytical research on efficiency, revenue recycling, double dividend, and environmental impacts based may be severely flawed.

\section{Theoretical Framework}

Principally, Pigouvian taxes internalize environmental externalities into markets (Pigou [9], Sandmo [1]). According to economic theory, an optimal environmental $\operatorname{tax}$ should be levied directly at the externality and equal the marginal damage cost (MDC) of the pollution. In contrast, the purpose of fiscal taxes is to raise revenue for publicly provided goods. Fiscal taxes should be levied where they are least likely to distort economic activity to avoid any deadweight loss. Under simplifying assumptions, e.g., disregarding externalities, the fiscal tax rate on a good should then be inversely proportional to the corresponding own price elasticity of demand (Ramsey [17], Diamond and Mirrlees [18]).

For polluting goods ${ }^{3}$, total taxes should vary according to the externality rule and the elasticity of demand by taking into account the additivity theorem in Sandmo $[1,16]$. Importantly, the optimal taxes will not simply be the sum of the fiscal tax and the $M D C$, rather a weighted average of the tax computed under the Ramsey inverse elasticity rule and the Pigouvian marginal social damage. More formally, let the weights be $a$ and $(1-a)$, and $T_{R}$ the inverse elasticity of demand. The optimal tax rate for the good then becomes:

$$
\begin{gathered}
T=a T_{R}+(1-a) M D C \\
0<a<1,
\end{gathered}
$$

where the first element reflects the fiscal element, and the second element reflects the Pigou element. The parameter $a$ then reflects the tightness of the government's budget constraint or the marginal cost of public funds (Sandmo [16]).

Consistent guidelines for environmental tax calculations should take this additivity theorem into account. We continue by developing a framework including this

\footnotetext{
$\overline{{ }^{3} \text { A polluting good should be defined as closely to the externality as }}$ possible, i.e. in most cases in terms of environmentally damaging emissions. It may also be in terms of the quantities of goods causing the emission. E.g, since the $\mathrm{CO}_{2}$ emissions and the use of gasoline are proportional, carbon taxes on petrol can be levied at the energy use, rather than the emissions.
} 
element. When decomposing the total revenue into its respective fiscal and environmental elements, each ascribed part $\left(a T_{R}\right.$ and $\left.(1-a) M D C\right)$ will be equal to or lower than the respective optimal fiscal and Pigouvian taxes $\left(T_{R}\right.$ and $\left.M D C\right)$. As such, the higher the government's budget requirement, the lower the weight of the environmental element. Hence, the environmental tax rate counts for only a share of marginal social damage:

$$
\text { Environmental tax }=(1-a) M D C \leq M D C \text {. }
$$

The theoretical framework refers to an optimal situation where the value of $a$ is a simple function of the shadow prices on the public and private budget constraints. Thus, $a$ is the same for all goods and all tax rates. In practice, the formulation of the tax system generally deviates from the theoretical framework because of market failures, conflicting political stands, pressure groups and considerations other than pure efficiency concerns. Consequently, $a$ varies over goods. In practice, goodsand tax-specific estimates do not exist, and so it is not clear how one should decompose an observed tax rate into a fiscal contribution and the share ascribed to $M D C$. This is not an argument against using the general principles underlying the optimal tax structure as guidelines when evaluating the actual tax structure. It is difficult to see how one can avoid arbitrariness in the evaluations when using a theoretically optimal structure as a reference for the evaluation. We should regard the weighted average in (1) as one such principle. Moreover, as we demonstrate, one can derive policy-relevant conclusions concerning the actual tax structure without knowledge of the weights.

We provide two separate cases, when the applied tax rate $T$ is set higher and lower than $T^{*}, T^{*}$ being the optimal tax rate where $T^{*}=M D C=M A C$.

Figure 1 illustrates the case the tax is higher than the optimal tax rate, under the general assumptions of increasing marginal abatement costs and increasing marginal damage costs. In this case, the tax is also higher than the marginal damage at the actual emission level, $T$ $=T^{h}>T^{*}>M D C^{\prime}$. The revenue from the tax equals both shaded areas. This revenue includes more than the optimal Pigouvian tax and the marginal social damage. Contrary to what may be perceived as standard intuition, part of the total revenue, i.e., corresponding to at least $T^{h}-$ $M D C^{\prime}$, is then classified as fiscal and should be subtracted from the revenue. The question is how much. As long as $a$ in practice is unknown, we do not obtain any assistance from theory. To define the entire $M D C^{\prime}$ as the environmental tax is rather radical in that it implies that the marginal cost of funds $(a)$ is zero, cf. (2). An approximation is to identify $M D C^{\prime}$ times the emission as an estimate of the maximal environmental tax revenue.

Discrimination of e.g. carbon taxes are common out of

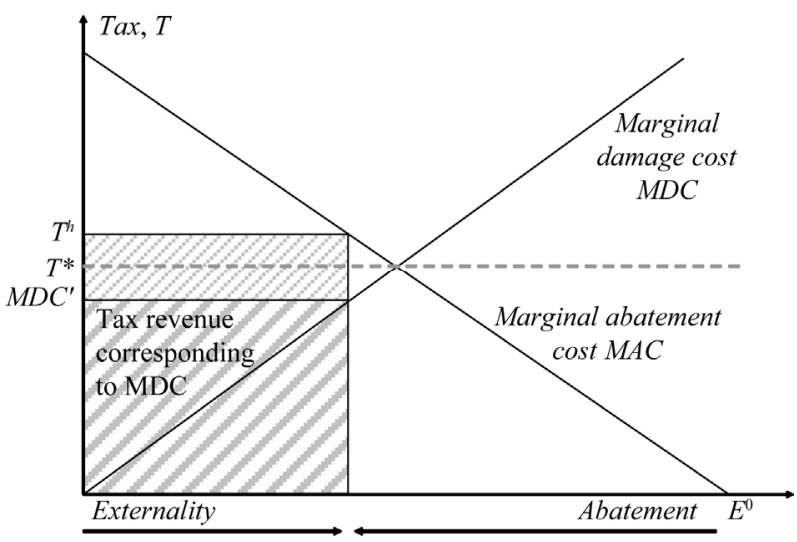

Figure 1. Tax higher than marginal damage cost.

competitiveness concerns (Babiker et al. [19]). Typically, taxes are relatively high for emission sources with low price elasticites, such as transport and residential heating (Bruvoll and Larsen [20]). Clearly, it is debatable what is the "correct" level of $M D C$ estimate for greenhouse gas emissions and other externalities. This must rely on different estimates in the literature. Given that the $M D C$ estimates are agreed upon, the taxes higher than $M D C$ estimates have no foundation in environmental taxation, but rather involve efficiency losses, since the marginal abatement costs are larger than the marginal benefits. Instead, these should be counted as non-environmental, or fiscal, taxes. Also, the fact that the Ramsey elasticity rule closely corresponds with the differentiation of the taxes, indicates that fiscal considerations heavily influence the politicians' determinations of carbon tax levels.

We find many examples of taxes set equal to the estimated marginal costs. In other instances, taxes are differentiated and certain industries face lower tax rates than the assumed $M D C$ s out of competitiveness concerns. This represents the cases where $T=T \leq T^{*}$, the tax is equal to or lower than the marginal damage, $T^{l} \leq M D C^{\prime \prime}$ at the actual emission level, see Figure 2. Typically, sectors with high price elasticites are exempt from the tax, or face lower rates (Bruvoll and Larsen [20]). Even if the tax is lower than the $M D C$, the environmental tax is principally lower than the applied tax level, given that $a>0$. Again, defining the entire revenue as environmental tax revenue implies an assumption that the marginal cost of funds, and hence the Ramsey tax, is equal to zero. As above, given that $a$ is unknown, the revenue from the tax $T^{l}$ can be defined as an estimate for the maximal environmental tax revenue.

This implies the following rules for the calculation of environmental taxes and their respective revenues:

- Rule 1: If the tax rates on pollution are higher than the $M D C$, the revenues according to the estimates of the $M D C$ equal the estimates of the maximum environmental tax revenues. 


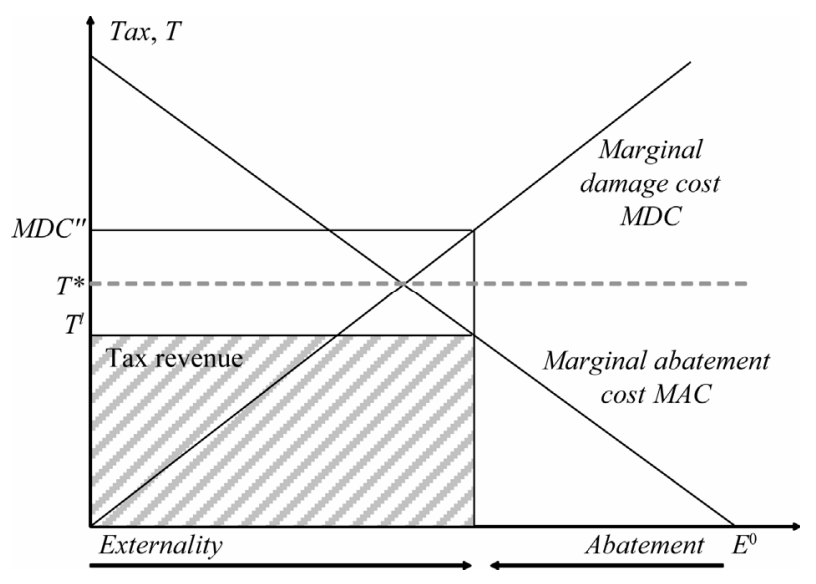

Figure 2. Tax lower than marginal damage cost.

- Rule 2: If the tax rates on pollution are equal to or lower than the $M D C$, the full revenues equal the estimates of the maximum environmental tax revenues.

- Rule 3: If $a$ is known, the maximum environmental $\operatorname{tax}$ should be corrected accordingly by a rate $(1-a)$ to obtain a closer estimate of the environmental taxes and the accordant environmental tax revenues.

\section{Use of the Framework and Comparison with the Official International Statistics}

To investigate the impact of using a theoretically based framework, we calculate the related revenues and compare them with the numbers reported in the international statistics (Eurostat [5]).

As the $M D C$ values cannot be observed in the market, our calculations are based on $M D C$ estimates $^{4}$. According to our Rule 1, we subtract the difference between the tax rates and the $M D C$ estimates when the tax rates are higher than the $M D C$ estimates to obtain the maximum environmental tax revenues. Total taxes on greenhouse gases contribute to the largest share of the total income from taxes on emissions in Norway, amounting to 1081 million euros, see Table 1. Due to the global, long-term and uncertain nature of the effects of greenhouse gases and varying effects across regions, it is particularly problematic to choose $M D C$ estimates for these emissions. As a point of departure, we used the highest price of emission permits in the EU ETS 2007 (25 euros per tonne $\mathrm{CO}_{2}$ ). This price level is also in line with the average Norwegian $\mathrm{CO}_{2}$ tax, which may be a proxy of the willingness to pay for $\mathrm{CO}_{2}$ reductions in Norway. The tax on $\mathrm{CO}_{2}$ emissions from petroleum activities on the continental shelf and on gasoline were about 50 - 80 per-

\footnotetext{
${ }^{4}$ Environmental economics theory offers several methods for estimating the values of environmental externalities as approximations of the true shadow prices, the most important being contingent valuation, hedonic pricing, travel costs, choice experiments and market-based methods (see, e.g., Pearce and Turner [21]).
}

Table 1. Real revenues from Norwegian environmental taxes, and revenues according to the OECD, Eurostat and IEA definition in millions of euros, 2007.

\begin{tabular}{|c|c|c|}
\hline & $\begin{array}{l}\text { Revenues from } \\
\text { environmental } \\
\text { taxes }\end{array}$ & $\begin{array}{l}\text { OECD, } \\
\text { Eurostat, } \\
\text { IEA statistics }\end{array}$ \\
\hline Taxes on greenhouse gases (Rule 1) & 715 & 1081 \\
\hline $\begin{array}{c}\text { Taxes on sulfur (Rule 1) } \\
\text { Taxes on NOx, waste incineration, } \\
\text { beverage containers, pesticides, } \\
\text { trichloroethane and tetrachloroethane } \\
(\text { Rule } 2)\end{array}$ & 246 & 248 \\
\hline Petrol and diesel taxes (Rule 2) & 655 & 1816 \\
\hline $\begin{array}{l}\text { Other taxes according to the OECD, } \\
\text { Eurostat, IEA guidelines }{ }^{2}\end{array}$ & 0 & 5083 \\
\hline Total & 1616 & 8228 \\
\hline
\end{tabular}

${ }^{1}$ Data reported to Eurostat/OECD (Næss and Smith 2009, Eurostat 2011). ${ }^{2}$ Motor vehicle registration tax, reregistration tax on motor vehicles, annual motor vehicle tax, annual weight-based tax on motor vehicles, electricity consumption tax, tax on mineral oils, tax on lubricating oil, base tax on disposable beverage packaging.

cent higher and taxes on greenhouse gases from landfills four times higher than the $M D C$ estimate. Rule 1 also applies for the sulfur tax on mineral products. This tax addresses environmental externalities associated with acid rain. Relative to the target set in the Gothenburg Protocol, the tax is 13 percent higher than the corresponding marginal abatement cost (Ministry of Finance [22]). We reduced the revenue accordingly.

The remaining environmental taxes in Table 1 are emission taxes set equal to or lower than according $M D C$ estimates, c.f. Rule 2. These taxes include taxes on $\mathrm{NO}_{\mathrm{x}}$, emissions from waste incineration, environmental costs associated with beverage containers, pesticides, trichloroethane and tetrachloroethane, and the share of the petrol and diesel taxes including road transport related emissions and noise 5 .

According to Sandmo and Rule 3, the fiscal element should also be separated from the taxes. Principally, correct adjustment requires a specific $a$ for each taxed good, but such estimates are not available. Estimates on the average marginal cost of funds in the Norwegian economy vary between 20 and 50 percent (Brendemoen and

\footnotetext{
${ }^{5}$ The taxes on $N O_{x}$ emissions are designed to meet agreed targets under the Gothenburg Protocol. The taxes are lower than the estimated optimal tax to reach the emission target (Ministry of Finance [22]), $T<$ $M D C$, cf. Figure 2. The Norwegian tax on waste incineration is adjusted to correspond to the estimated $M D C$. The taxes on pesticides, trichloroethylene and tetrachloroethylene are considered to have fulfilled their intentions with respect to emission reductions (Ministry of Finance [22]), cf. a reduction to the optimal level at $M D C=M A C$ in the figures above. The taxes on beverage containers assumedly reflect the $M D C$ (Raadal et al. [23]). The MDCs related to local road emission and noise are estimated to constitute about a quarter of total taxes on petrol and diesel fuels (ECON [24]).
} 
Vennemo [25], Holmøy and Strøm [26]). The rule of thumb in the Norwegian public sector allows for an average marginal cost of 20 percent (Ministry of Finance [27]). Using this as an estimate, the environmental tax revenues should be further reduced. If we use 20 percent as an approximate, we estimate the total environmental taxes in Norway to about 1300 euros.

\section{The International Statistics}

The Norwegian tax revenues according to the definition for the international statistics, published in the OECD/ Eurostat/IEA database, amount to 8200 million euros (Næss and Smith [28], Eurostat [5]), cf. Table 1. This is more than five times the environmental tax revenues according to our economic theory-based definition. The difference is partly due to the reduction of the surplus fiscal elements according to Rule 1 outlined above. The main reason however, is the inclusion of a range of purely fiscal taxes in the international statistics. As pointed out also by OECD [7], creating any definition of environmentally related taxes is problematic. Taxes have been implemented for a number of reasons, and some taxes have likely been implemented without stringent assessment of the costs and damages of the pollution. This contributes to explain why the international statistics rely on a broad definition. The EU, OECD and IEA refer to an "environmentally related tax" as "A tax whose tax base is a physical unit (or a proxy of it) of something that has a proven, specific negative impact on the environment. It was decided to include all taxes on energy and transport in the definition of environmental taxes. Value added type taxes are excluded from the definition (Eurostat [4] $)^{6}$. As all manufacturing requires factor inputs with a negative environmental impact, and all taxes and charges affect pollution through the equilibrium effects, this definition in principle covers all taxes and economic activities. The framework excludes some large tax bases, such as VAT and taxes on oil and gas, but without any principal justification?

The lack of theoretical foundation creates disturbing adjustments that increase the gap between statistics and a consistent and interpretable framework. For example, the statistics include the full revenues from petrol and diesel

\footnotetext{
${ }^{6} \mathrm{~A}$ specified list of tax bases is included in the guidelines (Eurostat [4]). ${ }^{7}$ Neither VAT nor resource taxes should be included according to theory, as neither are directed toward externalities. VAT is fiscal taxes, and resource taxes are normally imposed to tax economic rents on the extraction of natural resources (including Ricardian, Hotelling and monopoly rents). However, the reasoning for excluding them is not based on theoretical principals. VAT are excluded on the erroneous argument that they do not influence relative prices in the same way as taxes on environmentally related tax bases and Eurostat justifies the exclusion of resource taxes by invoking the wide variation in revenue from taxing oil and gas and across national tax systems. Hence, data is adjusted to avoid variation in the use of instruments.
}

taxes, i.e., the costs related to road usage and accidents, and all other fiscally motivated transport-related taxes except VAT. E.g., the numbers include the motor vehicles registration tax, whose original purpose was to create revenue for the state (Ministry of Finance [22]), see line 4 in Table 1. Indeed, the tax has a differentiated element according to $\mathrm{CO}_{2}$ emissions, but defining this as environmental would in any case imply double counting, as $\mathrm{CO}_{2}$ and the other environmental externalities from road traffic are already internalized in user-dependent tax bases. This also applies for the annual tax on motor vehicles that is higher for vehicles without particle filters. The purpose of other transport-related taxes (the reregistration tax, annual tax and the weight-based tax on motor vehicles) is mainly to fund infrastructure.

The international statistics also include the entire electricity consumption tax on electric power. Consumption of electricity has no known adverse environmental effects; the externalities origin from the production of power. The electricity good is based on a mixture of production technologies, ranging from zero emissions (e.g. wind, nuclear and hydro power) to emission intensive technologies (fossil fuels), and consumption taxes are only consistent to theory if they constantly vary with the current energy mix. According to theory, any pollution related to production should be regulated at the emission sources. Given taxes on power production, consumption taxes should not be included as it would imply double counting. Finally, 100 percent of Norwegian electricity production is based on renewable energy sources, and hence emission free. Hence, our judgment is that the Norwegian electricity consumption tax does not include any Pigouvian tax elements. The purpose of the tax on lubricating oils is to fund a collection system and the responsible handling of oil waste. Consequently, it should be considered a charge covering the costs of abated emissions, not an environmental tax covering the costs of the remaining emissions. For the remaining taxes included by Eurostat and other (the taxes on mineral oils and disposable beverage packaging), we base our judgment on the Ministry of Finance [22], and conclude that these taxes are pure fiscal taxes.

Environmental tax and revenue calculations require careful examination of the set of special duties in the light of tax theory for each country, evaluations of the marginal damage costs and the marginal rate of fund. All environmental tax calculations are thus encumbered with uncertainty. For example, the marginal costs of greenhouse gas emissions are particularly uncertain and subject to normative judgments. It is clearly debatable whether the EU ETS price, as we used, is the most relevant estimate. The $M D C$ may be defined as the necessary global carbon price to stabilize the atmospheric concentration at a widely agreed level. Globally efficient solutions 
implies the lowest possible price, while the price may be higher than any current $\mathrm{CO}_{2}$ tax if only a group of countries should contribute to the necessary emission reductions. However, these questions are out of scope of this paper, and do not influence the principal theoretical problems in the production of environmental tax statistics. Our aim in the empirical part of the paper is to illustrate the potential gains from basing the statistics on a theoretically consistent framework. Even with a wide range of uncertainty, our comparisons strongly indicate that the current international statistics present estimates that are too imprecise to indicate the extent of environmental taxes.

\section{Discussion}

International environmental tax statistics could be valuable inputs in research and political decisions, and as indicators for the use of economic instruments in the environmental policy and the environmental protection over time and across countries. Creating any definition of environmentally related taxes is inherently problematic. The entanglement with fiscal and other taxes complicates the calculation of these statistics. The problem is twofold. First, part of any tax on polluting emissions includes a fiscal element. Contrary to standard approximation, the environmental tax element is generally even lower than the marginal damage cost in the presence of fiscal taxes. This should be corrected when calculating environmental tax revenues. Second, the present official international statistics incorrectly include pure fiscal taxes and other non-environmental tax bases. Due to such conceptual challenges, the definition underlying the official international environmental tax statistics include a too wide range of tax bases.

This paper suggests theoretically consistent guidelines for the calculations of environmental taxes, starting with the theoretical definition of Pigou taxes and the additivity theorem (Sandmo [1]), and illustrates the potential measurement failure empirically.

Using Norwegian taxes as an example, we find that the tax revenues as published by official international statistics (OECD, Eurostat and IEA) are several times higher than the environmental tax revenues following our theory based definition. This is a serious warning that scientists using the international data can draw misleading conclusions on the causes and effects of environmental policy (see, e.g., Ekins [14], Sterner and Köhlin [13], Morley [15], Eurostat [5]).

It is fundamental for the reliability that the underlying principles for the official data are based on robust and consistent theory. The framework presented in this paper represents principal economic theory and significantly improves the statistics on environmental tax revenues, and the statistics' relevance to research and international comparisons of Pigouvian taxes.

\section{Acknowledgements}

The author is grateful to Torstein Bye and Erling Holmøy for valuable comments on an earlier version of this paper.

\section{REFERENCES}

[1] A. Sandmo, "Optimal Taxation in the Presence of Externalities," Swedish Journal of Economics, Vol. 77, No. 1, 1975, pp. 86-98. doi:10.2307/3439329

[2] A. L. Bovenberg, "Green Tax Reforms and the Double Dividend: An Updated Reader's Guide," International Tax and Public Finance, Vol. 6, No. 3, 1999, pp. 421-449. doi:10.1023/A:1008715920337

[3] L. H. Goulder and I. W. H. Parry, "Green Tax Reform and the Double Dividend," AERE Newsletter, Vol. 20, No. 1, 2000, pp. 9-13.

[4] Eurostat, "Environmental Taxes - A Statistical Guide," Office for Official Publications of the European Communities, Luxembourg, 2001.

[5] Eurostat, "Taxation Trends in the European Union. Data for the EU Member States, Iceland and Norway," Eurostat Statistical Books, Publications Office of the European Union, Luxembourg, 2011.

[6] Organisation for Economic Co-operation and Development (OECD), "Database on Environmental Policy Instruments," 2010. www.oecd.org/env/policies/database

[7] Organisation for Economic Co-operation and Development (OECD), "Taxation, Innovation and the Environment, OECD Green Growth Strategy," OECD, Paris, 2010.

[8] United Nations, "Outcome Paper for Global Consultation," Issue 6: Environmentally Related Taxes, Department of Economic and Social Affairs, Statistics Division, New York, 2011.

[9] A. C. Pigou, "The Economics of Welfare," Macmillian, London, 1920.

[10] T. Bye and A. Bruvoll, "Multiple Instruments to Change Energy Behaviour: The Emperor's New Clothes?" Energy Efficiency, Vol. 1, No. 4, 2008, pp. 373-386. doi:10.1007/s12053-008-9023-9

[11] European Environment Agency, "Market-Based Instruments for Environmental Policy in Europe," EEA Technical Report No. 8, European Environment Agency, Copenhagen, 2005.

[12] OECD, "The Political Economy of Environmentally Related Taxes," OECD, Paris, 2006.

[13] T. Sterner and G. Köhlin, "Environmental Taxes in Europe," Public Finance and Management, Vol. 3, No. 1, 2003, pp. 117-142.

[14] P. Ekins, "European Environmental Taxes and Charges: Recent Experience, Issues and Trends," Ecological Economics, Vol. 31, No. 1, 1999, pp. 39-62. doi:10.1016/S0921-8009(99)00051-8

[15] B. Morley, "Empirical Evidence on the Effectiveness of 
environmental Taxes," Bath Economic Research Papers, No. 2, University of Bath, Bath, 2010.

[16] A. Sandmo, "The Public Economics of the Environment," Oxford University Press, Oxford, 2000. doi:10.1093/019829798X.001.0001

[17] F. Ramsey, "A Contribution to the Theory of Taxation," Economic Journal, Vol. 37, No. 145, 1927, pp. 47-61. doi: $10.2307 / 2222721$

[18] P. Diamond and J. Mirrlees, "Optimal Taxation and Public Production I: Production Efficiency," American Economic Review, Vol. 61, No. 1, 1971, pp. 8-27.

[19] M. H. Babiker, P. Criqui, A. D. Ellerman, J. M. Reilly and L. L. Viguier, "Assessing the Impact of Carbon Tax Differentiation in the European Union," Environmental Modeling and Assessment, Vol. 8, No. 3, 2003, pp. 187197. doi:10.1023/A:1025543207122

[20] A. Bruvoll and B. M. Larsen, "Greenhouse Gas Emissions in Norway: Do Carbon Taxes Work?" In: T. Sterner and A. Muller, Eds., Environmental Taxation in Practice, Ashgate Publishing Limited, Aldershot, 2006.

[21] D. W. Pearce and R. K. Turner, "Economics of Natural Resources and the Environment," Harverster Wheatsheaf, Ashford Colour Press Ltd., Gosport, Hampshire, 1990.
[22] Ministry of Finance, "An Evaluation of Excise Taxes," Ministry of Finance (Norway), Oslo, 2007. (in Norwegian)

[23] H. L. Raadal C. A. Nyland, I. S. Modahl and O. J. Hanssen, "Environmental Valuation of Recyclable PET Drinking Bottles in Norway," Stiftelsen Østfoldforskning, Fredrikstad, 2003. (in Norwegian)

[24] ECON, "Marginal External Transport Costs," Rapport 2003-054, ECON Analyse, Oslo, 2003. (in Norwegian)

[25] A. Brendemoen and H. Vennemo, "The Marginal Cost of Funds in the Presence of Environmental Externalities," Scandinavian Journal of Economics, Vol. 98, No. 3, 1996, pp. 405-422. doi:10.2307/3440734

[26] E. Holmøy and B. Strøm, "The Social Cost of Government Spending in an Economy with Large Tax Distortions: A CGE Decomposition for Norway," Discussion Papers 396, Statistics Norway, Oslo, 2004.

[27] Ministry of Finance, "Benefit-Cost Analyses," Ministry of Finance (Norway), Oslo, 1998. (in Norwegian)

[28] E. M. Næss and T. Smith, "Environmentally Related Taxes in Norway. Totals and Divided by Industry," Documents 5, Statistics Norway, Oslo, 2009. 